\title{
"Plasma Concentration-Time Profile" as an Indefinite Claim Term: A Lesson from Forest Labs., Inc. v. Teva Pharm. USA, Inc.
}

\author{
By PING-HSUN CHEN
}

\begin{abstract}
Forest Labs., Inc. v. Teva Pharm. USA, Inc., 716 F. App'x 987 (Fed. Cir. 2017), teaches that when "human pharmacokinetic study" is read into a claim, the specification should identify the experimental conditions for such human pharmacokinetic (PK) study in detail to prevent the claim from being held indefinite under 35 U.S.C. $\S$ 112. The description of such a human PK study should include a route of administration, dosage regimen, blood sampling technique, and characteristics of subjects, as required in the academic context. For those pending applications where the specification fails to provide a particular human PK study, a declaration made by the inventors may be submitted to clarify that.
\end{abstract}

\section{INTRODUCTION}

$\mathrm{E}$ FFICACY OF A DRUG PRODUCT depends on the drug concentration at the targeted site of a human body after administrating such drug product. ${ }^{1}$ Pharmacokinetics studies drug concentrations of a given dose during four stages after administration: absorption, distribution, metabolism, and excretion (called ADME processes). ${ }^{2}$ "Absorption" means the transfer of drug molecules from the administration site to the blood. "Distribution" means the transfer from the blood to a target. "Metabolism" means biotransformation of the drug molecules. ${ }^{5}$ "Excretion" means removal of the transformed molecules from the body through urines, bile, or other routes. $^{6}$

Keywords: patent, indefiniteness, plasma concentration, pharmacokinetics, abbreviated new drug application

Ping-Hsun Chen is Associate Professor at the Graduate Institute of Technology, Innovation, and Intellectual Property Management at National Chengchi University in Taipei, Taiwan. Mr. Chen holds a JD ('10) and LLM ('08) from Washington University in St. Louis School of Law; an LLM ('07) from National Chengchi University in Taiwan; and a BS ('97) and MS ('99) in Chem. Eng. from National Taiwan University in Taiwan. E-mail for Mr. Chen: cstr@nccu.edu.tw
Pharmacokinetic (PK) studies are used to find out therapeutic doses with an adequate profile of drug concentration versus time. " Drug concentration" is derived by collecting a blood sample at any time after drug administration and measuring the amount of a drug in a given volume of blood

${ }^{1}$ See David Brown and Mark Tomlin, Pharmacokinetic Principles, in Pharmacology \& Pharmacokinetics 13, 13 (Mark Tomlin ed., Springer-Verlag London 2010). Efficacy is referred to as " $[\mathrm{t}]$ he capacity of a drug to induce a therapeutic effect." Daniel L. Gustafson and Erica L. Bradshaw-Pierce, Fundamental Concepts in Clinical Pharmacology, in Principles of Anticancer Drug Development, Cancer Drug Discovery and Development 37, 39 (M. Hidalgo et al. eds., Springer Science+Business Media, LLC 2011).

${ }^{2} \mathrm{See}$ Younggil Kwon, Handbook of Essential Pharmacokinetics, Pharmacodynamics and Drug Metabolism FOR Industrial ScIEntists 1 (Kluwer Academic Publishers 2002).

${ }^{3}$ See R. Urso, P. Blardi, and G. Giorgi, A Short Introduction to Pharmacokinetics, 6 Eur. Rev. Med. \& PharmacologICAL SCI. 33, 33 (2002), available at http://www.european review.org/wp/wp-content/uploads/6.pdf (last visited Dec. 28, 2018).

${ }^{4}$ See id.

${ }^{5}$ See id.

${ }^{6}$ See id.

${ }^{7}$ See Kwon, supra note 2, at 1-2. 
plasma of the sample. ${ }^{8}$ The measured drug concentration is generally known as "plasma concentration." 9

A profile of plasma concentration versus time can be used to characterize the therapeutic effect of a drug for a specific dosage or formulation. ${ }^{10}$ Thus, "plasma concentration-time profile" is a limitation commonly used in pharmaceutical product claims or treatment claims. For example, in Purdue Pharma L.P. v. Faulding Inc. ${ }^{11}$ claim 1 of the disputed patent, U.S. Patent No. 5,672,360 (hereinafter'360 Patent), recites:

A method of effectively treating pain in humans, comprising orally administering to a human patient on a once-a-day basis an oral sustained release dosage form containing an opioid analgesic or salt thereof which upon administration provides a time to maximum plasma concentration $\left(T_{\max }\right)$ of said opioid in about 2 to about 10 hours and a maximum plasma concentration $\left(C_{\max }\right)$ which is more than twice the plasma level of said opioid at about 24 hours after administration of the dosage form, and which dosage form provides effective treatment of pain for about 24 hours or more after administration to the patient. $^{12}$

Claim 1 of the ' 360 Patent uses two pharmacokinetic parameters. ${ }^{13}$ "Maximum plasma concentration" means the highest drug concentration after administration, while "a time to maximum plasma concentration" means the time at which the highest drug concentration is observed. ${ }^{14}$

Another way to recite "plasma concentrationtime profile" is shown in In re Cyclobenzaprine Hydrochloride Extended-Release Capsule Patent Litig. ${ }^{15}$ where two patents-in-suit, U.S. Patent Nos. $7,387,793$ (claiming a dosage form of a skeletal muscle relaxant) and 7,544,372 (claiming a method of relieving muscle spasms) both have a dependent claim reciting:

[A] maximum blood plasma concentration $\left(\mathrm{C}_{\max }\right)$ within the range of about $80 \%$ to $125 \%$ of about $20 \mathrm{ng} / \mathrm{mL}$ of cyclobenzaprine $\mathrm{HC} 1$ and an $\mathrm{AUC}_{0-168}$ within the range of about $80 \%$ to $125 \%$ of about $740 \mathrm{ng} \cdot \mathrm{hr} / \mathrm{mL}$ and a $\mathrm{T}_{\max }$ within the range of $80 \%$ to $125 \%$ of about 7 hours following oral administration ... ${ }^{16}$

The dependent claim uses another pharmacokinetic parameter, AUC, which means the area under the plasma concentration-time curve and can be calculated from a plasma concentrationtime profile. ${ }^{17}$

A third way to recite "plasma concentrationtime profile" is to compare the profile of the claimed invention to that of another drug formulation. In Abbott Labs. v. Andrx Pharm., Inc., ${ }^{18}$ claim 4 of the patent-in-suit, U.S. Patent No. 6,010,718 recites:

[A] pharmaceutical composition for extended release of an erythromycin derivative in the gastrointestinal environment, comprising ... so that upon oral ingestion, maximum peak concentrations of the erythromycin derivative are lower than those produced by an immediate release pharmaceutical composition, and area under the concentration-time curve and the minimum plasma concentration

\footnotetext{
${ }^{8}$ See Kwon, supra note 2, at 4-6; see also Siamak Cyrus Khojasteh, Harvey Wong, and Cornelis E.C.A. Hop, Drug Metabolism and Pharmacokinetics Quick Guide 2-4 (Springer 2011); NATIONAL LibRARY OF MEDICINE, AIDSINFo Glossary OF HIV/AIDS-RElated Terms 49 (9th ed. 2018) ("The amount of a drug in a given volume of blood plasma, measured as the number of micrograms per milliliter."), available at https://aidsinfo.nih.gov/content files/glossaryhivrelatedterms_english.pdf (last visited Oct. $18,2018)$. But the measurement may be based on a given volume of blood or serum. See Dion R. Brocks, Pharmacokinetics in Preclinical Drug Development: An Overview, in Evaluation of Drug Candidates for Preclinical Development: Pharmacokinetics, Metabolism, PharMaceutics, AND Toxicology 11, 14 (Chao Han, Charles B. Davis, and Binghe Wang eds., John Wiley \& Sons, Inc. 2010). ${ }^{9}$ See Brocks, supra note 8, at 14.

${ }^{10}$ See Hendrika Laetitia Hattingh, Pharmacists' Responsibility and Potential Liability Regarding Generic Substitition, 28 MED. \& L. 697, 698 (2009) ("Two medicines are considered bioequivalent when they produce such similar plasma concentrations of the active ingredient that their clinical effects can be expected to be the same.").

${ }^{11}$ Purdue Pharma L.P. v. Faulding Inc., 230 F.3d 1320 (Fed. Cir. 2000).

${ }^{12} I d$. at $1322-23$ (emphasis added).

${ }^{13}$ See U.S. Patent No. 5,672,360 col.16 11.24-34; see also KHOJASTEH, Wong, AND HoP, supra note 8, at 1-4.

${ }^{14}$ See Kwon, supra note 2, at 6; see also U.S. Patent No. 5,672,360 col.20 11.55-57.

${ }^{15}$ In re Cyclobenzaprine Hydrochloride Extended-Release Capsule Patent Litig., 676 F.3d 1063 (Fed. Cir. 2012).

${ }^{16}$ In re Cyclobenzaprine, 676 F.3d at 1066-67; see also U.S. Patent No. 7,387,793 claim 3; U.S. Patent No. 7,544,372 claim 3.

${ }^{17}$ See Kwon, supra note 2, at 18-19.

${ }^{18}$ Abbott Labs. v. Andrx Pharm., Inc., 452 F.3d 1331 (Fed.
} Cir. 2006). 
are substantially equivalent to that of the immediate release pharmaceutical composition. ${ }^{19}$

"Plasma concentration-time profile" as a claim term has been subject to patentability issues. ${ }^{20}$ One of those issues is indefiniteness under 35 U.S.C. $\S$ $112 .^{21}$ Currently, $\S 112$ requires that "[ $\left.\mathrm{t}\right]$ he specification shall conclude with one or more claims particularly pointing out and distinctly claiming the subject matter which the inventor or a joint inventor regards as the invention." 22 The standard for determining definiteness has been settled in the Supreme Court's Nautilus, Inc. v. Biosig Instruments, Inc. ${ }^{23}$ under which "a patent's claims, viewed in light of the specification and prosecution history, [must] inform those skilled in the art about the scope of the invention with reasonable certainty." 24

In 2017, the Federal Circuit, in Forest Labs., Inc. v. Teva Pharm. USA, Inc., ${ }^{25}$ invalidated the claimsin-suit because the claims were indefinite. ${ }^{26}$ The disputed claims included a "plasma concentrationtime profile" limitation reciting "a change in memantine concentration as a function of time $(\mathrm{dC} / \mathrm{dT})$ that is less than $50 \%$ that of an immediate release dosage form comprising the same dose of memantine as the composition[.]"27 The Federal Circuit found that the disputed limitation requires human-study comparisons that, however, are not described in the specification as to how to design pharmacokinetic studies in humans. ${ }^{28}$ Therefore, the Federal Circuit held the disputed limitation indefinite. $^{29}$

The Forest Labs., Inc. case was brought under the Hatch-Waxman Act by the plaintiffs/patentees to stop several generic drug companies from getting a drug permit for marketing their generic versions of Namenda XR through an abbreviated new drug application (ANDA). ${ }^{30}$ Namenda XR was a pioneer drug for treatment of moderate to severe $\mathrm{Alz}$ heimer's disease. ${ }^{31}$ There were six patents-in-suit covering pharmaceutical compositions and administration methods of Namenda XR. ${ }^{32}$ Namenda $\mathrm{XR}$ has been manufactured and sold by Forest Laboratories Inc. ("Forest") since it was approved by the U.S. Food and Drug Administration (FDA). ${ }^{33}$ Since the Namenda XR patents were invalidated by the Federal Circuit, one generic drug company has launched the marketing of their generic Namenda XR. ${ }^{34}$

This article will address what may be learned from Forest Labs., Inc. in terms of patent drafting and prosecution. Part II introduces the background of Forest Labs., Inc. and analyzes the Federal Circuit's decision. Part III discusses lessons learned from Forest Labs., Inc. by explaining experimental conditions for human PK studies, analyzing the specification of the representative patent-in-suit, and proposing a practical solution for those pending applications in similar situations to the patentsin-suit in Forest Labs., Inc.

${ }^{19}$ Abbott Labs., 452 F.3d at 1337 (emphasis added); see also U.S. Patent No. 6,010,718 claim 4.

${ }^{20}$ See, e.g., Purdue Pharma L.P. v. Faulding Inc., 230 F.3d 1320 (Fed. Cir. 2000) (written description); Abbott Labs. v. Andrx Pharm., Inc., 452 F.3d 1331 (Fed. Cir. 2006) (obviousness); In re Cyclobenzaprine Hydrochloride ExtendedRelease Capsule Patent Litig., 676 F.3d 1063 (Fed. Cir. 2012) (obviousness); Endo Pharm. Inc. v. Teva Pharm. USA, Inc., 731 F. App'x 962 (Fed. Cir. 2018) (indefiniteness), vacated in part on other grounds, 729 F. App'x 936 (Fed. Cir. 2018); Forest Labs., Inc. v. Teva Pharm. USA, Inc., 716 F. App'x 987 (Fed. Cir. 2017) (indefiniteness).

${ }^{21}$ See Forest Labs., Inc., 716 F. App'x at 994-95 (quoting 35 U.S.C. $\S 112$, ๆ 2 (2006) requiring that "[a] patent claim must "particularly point[ ] out and distinctly claim[ ] the subject matter which the applicant regards as his invention"" (alteration original)).

${ }^{22} 35$ U.S.C. $\S 112$ (b). This current version of 35 U.S.C. $\S$ 112 was originated from the Leahy-Smith America Invents Act ("AIA") and is applied to patents filed on or after September 16, 2012. See U.S. Patent and Trademark Office, Manual of Patent Examining Procedure $\S 2171$, https:// www.uspto.gov/web/offices/pac/mpep/s2171.html (last visited Dec. 6, 2018). The AIA version of 35 U.S.C. $\S 112$, ๆ 2 (2006) is 35 U.S.C. $\oint 112$ (b). See id.

${ }^{23}$ Nautilus, Inc. v. Biosig Instruments, Inc., 134 S. Ct. 2120 (2014).

${ }^{24}$ Nautilus, Inc., 134 S. Ct. at 2129. The Federal Circuit has adopted the Nautilus standard. See Interval Licensing LLC $v$. AOL, Inc., 766 F.3d 1364, 1369-70 (Fed. Cir. 2014); David O. Taylor, Amending Patent Eligibility, 50 U.C. Davis L. REv. 2149, 2184 (2017); see also Christopher M. Holman, The Supreme Court's Devaluation of U.S. Patents, 36 BIOTECHNOLOGY L. REP. 151, 153 (2017).

${ }^{25}$ Forest Labs., Inc. v. Teva Pharm. USA, Inc., 716 F. App'x 987 (Fed. Cir. 2017) [hereinafter Forest II].

${ }^{26}$ See id. at 988.

${ }^{27}$ Id. at $990-91$.

${ }^{28}$ See id. at $992-94$.

${ }^{29}$ See id. at $994-95$.

${ }^{30}$ See Forest Labs., Inc. v. Teva Pharm. USA, Inc., No. CV 14-1058-LPS, 2016 WL 54910, at*1 (D. Del. Jan. 5, 2016) [hereinafter Forest I].

${ }^{31}$ See id.

${ }^{32}$ See Forest II, 716 F. App'x at 989.

${ }^{33}$ See In re Namenda Direct Purchaser Antitrust Litig., No. 15 CIV. 7488 (CM), 2017 WL 4358244, at *7 (S.D.N.Y. May 23, 2017) [hereinafter Namenda].

${ }^{34}$ See Amneal Pharmaceuticals, Amneal Introduces Memantine Hydrochloride Extended-Release Capsules, Generic for Namenda XR®, PR NewswiRE, Feb. 21, 2018, https:// www.prnewswire.com/news-releases/amneal-introducesmemantine-hydrochloride-extended-release-capsules-genericfor-namenda-Xr-300601884.html (last visited Jan. 15, 2019). 


\section{ANALYSIS OF FOREST LABS., INC. V. TEVA PHARM. USA, INC.}

\section{A. Patented technology}

Alzheimer's disease (AD) is an irreversible and fatal form of dementia or neurological disorder. ${ }^{35} \mathrm{AD}$ patients usually suffer from "a gradual loss of memory, problems with reasoning or judgment, disorientation, difficulty in learning, loss of language skills, and decline in the ability to perform routine tasks." 36

Medications for treating $\mathrm{AD}$ can be divided into two categories. ${ }^{37}$ Razadyne (galantamine, formerly known as Reminyl), Exelon (rivastigmine), and Aricept (donepezil), for example, are drugs for treating mild to moderate $\mathrm{AD} .^{38}$ These drugs may slow down the worsening of $\mathrm{AD}$ symptoms for a limited period. ${ }^{39}$

On the other hand, Namenda (memantine), an Nmethyl D-aspartate (NMDA) antagonist, is prescribed to treat moderate to severe AD. ${ }^{40}$ Namenda drugs have been marketed in two formulations: a twice-daily immediate-release drug, Namenda IR, and a once-daily extended-release drug, Namenda $\mathrm{XR} .{ }^{41}$ Namenda IR, released immediately into the bloodstream, is taken by a patient twice a day, while Namenda XR, released gradually, is taken once a day. ${ }^{42}$

Namenda IR was first developed by Forest Laboratories Inc., which worked with Merz GmbH \& Co. KGaA, Merz Pharma GmbH \& Co. KGaA, and Merz Pharmaceuticals GmbH Merz (collectively, "Merz"). ${ }^{43}$ Merz owned patents covering Namenda IR and granted an exclusive license to Forest. ${ }^{44}$

Namenda IR was approved by the FDA on October $16,2003 .{ }^{45}$ Forest started to market Namenda IR in January $2004 .^{46}$ Since then, Namenda IR had generated a lot of revenue. ${ }^{47}$ However, when Forest saw generic drug companies begin to file ANDAs for Namenda IR, it decided to develop Namenda XR to replace Namenda IR. ${ }^{48}$

FDA approved Namenda XR on June 21, 2010. ${ }^{49}$ Forest began to market Namenda XR in July 2013. ${ }^{50}$ There were eight patents listed in the Approved Drug Products with Therapeutic Equivalence Evaluations ("Orange Book") as covering Namenda XR. ${ }^{51}$

\section{B. Disputed claim}

The Federal Circuit chose claim 1 of U.S. Patent No. 8,168,209 (hereinafter '209 Patent) as a representative claim for the indefiniteness analysis. ${ }^{52}$ Claim 1 recited:

A solid pharmaceutical composition in a unit dosage form for once daily oral administration comprising an extended release formulation of 5 to $40 \mathrm{mg}$ memantine or pharmaceutically acceptable salt thereof, wherein administration of a dose of the composition to a human subject provides a plasma memantine concentration profile, as measured in a single-dose human PK study, characterized by a change in memantine concentration as a function of time $(d C / d T)$ that is less than $50 \%$ that of an immediate release dosage form comprising the same dose of memantine as the composition, wherein the $\mathrm{dC} / \mathrm{dT}$ is measured between

${ }^{35}$ See Joseph Karl Grant, Running Past Landmines-the Estate Attorney's Dilemma: Ethically Counseling the Client with Alzheimer's Disease, 24 ELDER L.J. 101, 107 (2016). ${ }^{36} \mathrm{Id}$.

${ }^{37}$ See Alzheimer's Disease Education \& Referral (ADEAR) Center, Alzheimer's Disease Medications: FACT SheET, at 1, NIH Publication No. 08-3431, Nov. 2008, available at http://www.bu.edu/alzresearch/files/pdf/ ADEARMedicationsFactSheet3.pdf (last visited Oct. 11, 2018).

${ }^{38}$ See id.

${ }^{39}$ See id.

${ }^{40}$ See ADEAR CENTER, supra note 37, at 1; see also Peter V. Dicpinigaitis, Brendan J. Canning, Rachel Garner, and Blake Paterson, Effect of Memantine on Cough Reflex Sensitivity: Translational Studies in Guinea Pigs and Humans, 352 J. Pharmacology \& Experimental Therapeutics 448, 448 (2015), available at http://jpet.aspetjournals.org/ content/jpet/352/3/448.full.pdf (last visited Nov. 1, 2018).

${ }^{41}$ See New York ex rel. Schneiderman v. Actavis PLC, 787 F.3d 638, 646 (2d Cir. 2015).

${ }^{42}$ See id. at 647.

${ }^{43}$ See Forest II, 716 F. App'x at 988-89; see also New York ex rel. Schneiderman, 787 F.3d at 646-47; In re Namenda Direct Purchaser Antitrust Litig., No. 15 CIV. 7488 (CM), 2017 WL 4358244, at *2 (S.D.N.Y. May 23, 2017).

${ }^{44}$ See Namenda, 2017 WL 4358244, at *2.

${ }^{45}$ See id. at $* 5$.

${ }^{46}$ See id.

${ }^{47}$ See New York ex rel. Schneiderman, 787 F.3d at 646-47. ${ }^{48}$ See id. at 647-48.

${ }^{49}$ See U.S. Food and Drug Administration, Drug Approval Package-Namenda XR, https://www.accessdata.fda.gov/ drugsatfda_docs/nda/2010/

022525s000_namenda_xr_toc.cfm (last visited Jan. 15, 2019).

${ }^{50}$ See New York ex rel. Schneiderman, 787 F.3d at 647-48.

${ }^{51}$ See Forest I, 2016 WL 54910, at *1 ("There are eight patents-in-suit: U.S. Patent Nos. 8,168,209[, 8,173,708, $8,283,379,8,329,752,8,362.085,8,598,233,8,039,009$, and 5,061,703]."). But, when the case was appealed to the Federal Circuit, U.S. Patent Nos. 8,039,009 and 5,061,703 were not in dispute. See Forest II, 716 F. App'x at 989.

${ }^{52}$ See Forest II, 716 F. App'x at 990 ("The parties agreed that the language in claim 1 of [U.S. Patent No. $8,168,209]$ is representative."). 
the time period of 0 to Tmax of the immediate release form of memantine. ${ }^{53}$

The above-italicized part of claim 1 was found indefinite by the district court. ${ }^{54}$ The district court relied on intrinsic evidence to interpret the disputed claim and considered extrinsic evidence to determine indefiniteness. ${ }^{55}$

Regarding claim construction, the district court focused on the claim term "memantine concentration" and interpreted it as a value "observed as measured in a single-dose human PK study." 56 However, the district court found that the specification did not "disclose any human PK study [but merely showed] memantine concentration data generated from computer simulations." ${ }^{57}$ The only information concerning a human PK study was found in a declaration made by Dr. Gregory $\mathrm{T}$. Went, one inventor, (hereinafter "Went declaration") and submitted to the U.S. Patent and Trademark Office during prosecution of the patents-insuit. ${ }^{58}$ While recognizing the Went declaration as part of the intrinsic evidence, ${ }^{59}$ the district court nevertheless held that there was "no proper basis to limit the 'study' in the patents' claims ... to just the single study included with [the Went] declaration, as Plaintiffs suggest[ed] must be done."60 Therefore, the district court concluded that "any human PK study could be used to generate the memantine concentration data." ${ }^{61}$

Regarding indefiniteness, the district court considered the expert opinions submitted by both parties, ${ }^{62}$ because it initially found that "the intrinsic evidence [said] nothing about how a human PK study should be conducted." 63

The district court primarily relied on the defendant's expert opinion and found that "measurements from human PK studies vary widely in terms of the concentration profiles they generate." 64 Although the plaintiff's expert opined that a "person of ordinary skill in the art would rely on their training and experience to determine the appropriate design [of a human PK study] to use in a given set of circumstances," ${ }^{65}$ the district court found that the overall opinion failed to refute the defendant's expert opinion. ${ }^{66}$ Ultimately, the district court held that " $[\mathrm{t}]$ he claims and intrinsic evidence [did] not limit this term to a particular profile or human PK study or even a particular set of parameters with which one of ordinary skill in the art could design a study." 67

Furthermore, the district court pointed out that the evidence did not clarify "what Tmax value, or range of Tmax values, or even which subset of immediate-release profiles, would be proper refer- ence points for analyzing the ' $50 \%$ of the $\mathrm{dC} / \mathrm{dT}$ ' limitation." 68 Therefore, the disputed claims were found indefinite because "[f]or any given formulation of extended-release memantine, a potential infringer would not know with reasonable certainty whether it would be infringing[.]" 69

\section{Federal Circuit's reasoning}

On appeal, the plaintiff argued that the district court erred in requiring both to-be-compared plasma memantine concentration profiles of the extended-release formulation and immediaterelease formulation be measured through human PK studies. ${ }^{70}$ Instead, the plaintiff construed the profile for the extended-release formulation as being measured in a human PK study and the profile for the immediate-release formulation as being the computer-generated profile shown in Figures 1A and $2 \mathrm{D}$ of the specification. ${ }^{71}$ But, the Federal Circuit rejected these arguments. ${ }^{72}$

1. Claim construction. The Federal Circuit agreed with the district court's claim construction and held that "human-study comparisons are required." 73 The Federal Circuit's reasoning includes three parts. ${ }^{74}$

${ }^{53}$ See U.S. Patent No. 8,168,209 claim 1 (emphasis added); see also Forest Labs., Inc., 716 F. App'x at 990-91.

${ }_{54}^{54}$ ee Forest I, 2016 WL 54910, at *8.

${ }^{55}$ See id. at *8-*9.

${ }^{56} I d$. at $* 8$ (internal quotation marks omitted).

${ }^{57} I d$. (citing U.S. Patent No. 8,168,209 Figs. 1A, 2D).

${ }^{58}$ See Forest I, 2016 WL 54910, at *9; see also U.S. Patent No. 8,168,209 front page.

${ }^{59}$ See Forest I, 2016 WL 54910, at *9.

${ }^{60} I d$.

${ }^{61} I d$. (emphasis original).

${ }^{62}$ See id.

${ }^{63} I d$. (emphasis original).

${ }^{64} I d$. ("For example, Dr. Bergstrom cites reports of 'Tmax' values for immediate-release memantine that vary between 1.6 and 9.8 hours.").

${ }^{65} I d$. (alteration original) (quoting the plaintiff's expert opinion).

${ }^{66}$ See id.

${ }^{67} \mathrm{Id}$.

${ }^{68} I d$.

${ }^{69} I d$.

${ }^{70}$ See Forest II, 716 F. App'x at 992.

${ }^{71}$ See id. at $992-93$.

${ }^{72}$ See id. at 993.

${ }^{73} \mathrm{Id}$. at 994.

${ }^{74}$ See infra Part II.C.1. The Federal Circuit did not examine extrinsic evidence because the plaintiff did not bring that issue. See Forest II, 716 F. App'x at 994. 
The Federal Circuit started with the phrase "a plasma memantine concentration profile, as measured in a single-dose human PK study" (hereinafter "PK phrase") recited in claim 1 of the '209 Patent. ${ }^{75}$ While recognizing that the PK phrase was grammatically possibly read as "referring to only the profile of the extended-release formulation," ${ }^{76}$ the Federal Circuit held that the intrinsic evidence did not support such reading. ${ }^{77}$

Secondly, the Federal Circuit considered Figures 1A and 2D and their accompanying descriptions in the specification and concluded that they did not support that the plasma memantine concentration profile for the immediate-release formulation is computer-generated. ${ }^{78}$ The conclusion was based on a notion that " $[\mathrm{t}] \mathrm{he}$ descriptions of the figures are no more than what they purport to be: descriptions of the figures, [and they] do not constitute a definition and are not even directed to the meaning of the claim terms." 79

The Federal Circuit found that that the plasma concentration profiles for a $20 \mathrm{mg}$ memantine immediate-release formulation and a $20 \mathrm{mg}$ memantine extended-release formulation shown in these figures were generated by a software program called GastroPlus. ${ }^{80}$ But the Federal Circuit held that those descriptions were not enough to support the plaintiff's claim construction that the concentration profile for an immediate-release formulation recited in claim 1 is limited to the computergenerated profiles shown in Figures 1A and 2D. ${ }^{81}$

In addition, the Federal Circuit considered the definition of "dC/dT" in the specification. ${ }^{82}$ But the Federal Circuit criticized that "dC/dT" was not specifically used to describe the concentration profile for an immediate-release formulation. ${ }^{83}$ The Federal Circuit held that "dC/dT" was a "merely illustrative character of the figures" that show "profiles only for [immediate-release formulations of] particular doses, not profiles for the full range of doses covered by [claim 1] - for which immediate-release profiles are needed but not found in those figures." 84

The Federal Circuit further examined whether "Figures 1A and 2D define a fixed baseline for the claim-required comparison simply because they provide the only immediate-release concentration profile disclosed in the specification." ${ }^{85}$ But the Federal Circuit held that the answer is no because "the basic descriptions of Figures $1 \mathrm{~A}$ and 2D do not provide a clear point of comparison[.]" 86

Lastly, the Federal Circuit considered the prosecution history and focused on the Went declaration submitted during prosecution. ${ }^{87}$ The Federal Circuit found that the Went declaration described and compared "the results of a human pharmacokinetic study from which both immediate-release and extended-release profiles were derived[, rather than compared] the extended-release profile from the human study to the immediate-release profile in Figures 1A and 2D." 88 Thus, the Federal Circuit concluded that the declaration failed to support the plaintiff's claim construction. ${ }^{89}$

2. Indefiniteness determination. Regarding indefiniteness, the Federal Circuit agreed with the district court's ruling. ${ }^{90}$ First, the Federal Circuit examined the district court's factual findings and concluded that the ruling was supported by its case law that will find a claim indefinite if the claim requires

measured quantities (absolute or relative), different techniques for such measurements are known in the art and some produce infringing results and others not, the intrinsic evidence does not adequately specify the technique or techniques to use, and extrinsic evidence does not show that a relevant skilled artisan would know what technique or techniques to use. ${ }^{91}$

The Federal Circuit also considered the plaintiff's argument that the determination of indefiniteness should be based on the defendant's claim construction. ${ }^{92}$ Specifically, the plaintiff construed the disputed claim as requiring that both immediaterelease and extended-release profiles be measured in

${ }^{75}$ See Forest II, 716 F. App'x at 993 (quoting U.S. Patent No. 8,168,209 col. 37 11. 16-17).

${ }^{76} \mathrm{Id}$.

${ }^{77}$ See id.

${ }^{78}$ See id.

${ }^{79}$ Id.

${ }^{80}$ See id. (citing U.S. Patent No. 8,168,209 col. 6 11. 58-65, col. 7 11. 26-32).

${ }^{81}$ See id.

${ }^{82}$ See id. (citing U.S. Patent No. 8,168,209 col. 4 11. 36-38).

${ }^{83}$ See id.

${ }^{84}$ Id.

${ }^{85} \mathrm{Id}$.

${ }^{86} \mathrm{Id}$. at 994 .

${ }^{87} \mathrm{Id}$.

${ }^{88} \mathrm{Id}$.

${ }^{89}$ See id. at 994.

${ }^{90}$ See id. at $994-95$.

${ }^{91}$ Id. at 994 (citing Dow Chem. Co. v. Nova Chems. Corp. (Canada), 803 F.3d 620, 633-35 (Fed. Cir.), rehr'g denied, 809 F.3d 1223 (Fed. Cir. 2015); Honeywell Int'l, Inc. v. Int'l Trade Comm'n, 341 F.3d 1332, 1339-42 (Fed. Cir. 2003)).

${ }^{92}$ See id. at $994-95$. 
the same human PK study. ${ }^{93}$ But the Federal Circuit rejected the plaintiff's claim construction because the plaintiff actually opposed such construction in the district court and the case law did not allow a party to renew its claim construction on appeal. ${ }^{94}$

\section{LESSONS FOR RECITING PLASMA CONCENTRATION-TIME PROFILES IN A CLAIM}

\section{A. Complexity of human pharmacokinetic study design}

The Federal Circuit found the disputed claim indefinite, because no evidence supported that the "PK phrase" limitation is limited to a particular human PK study. ${ }^{95}$ The finding is pharmacologically correct. ${ }^{96}$ Designing a human PK study is complex and requires several considerations, such as "route of drug administration, dose regimen, tissues to sample, sample times, analytical method, [and] the inclusion and exclusion criteria of the [human] subjects." 97

The route of drug administration will affect drug absorption. ${ }^{98}$ An intravenous injection is a direct way to transfer drug molecules to the blood. ${ }^{99}$ Any other parenteral administrations require subsequent movement of drug molecules from the injection site to the general venous circulation, except for an intraarticular injection that provides a local effect. ${ }^{100}$ If an oral administration is used, it is necessary to control food consumption of subjects. ${ }^{101}$

"Dose regimen" means the frequency and total duration of repeated administrations. ${ }^{102}$ A dose regimen should be carefully determined, so that the plasma concentration can reach a steady state of the expected drug concentrations, giving a therapeutic effect. ${ }^{103}$ The determination of a dose regimen may be based on the time needed to reach the steady state. ${ }^{104}$ The drug may be administrated once or twice daily, or several times weekly, while the treatment may last for several days, weeks, or months. ${ }^{105}$

Blood sampling techniques (concerning tissues to sample, sample times, or analytical methods) may affect measurement of plasma concentrations. ${ }^{106}$ Plasma concentrations measured from central venous catheters (CVCs) and peripheral veins may be different for some drugs. ${ }^{107}$ In addition, the timing, frequency, and duration of blood sample collection depend on the expected decline of plasma concentrations. ${ }^{108}$

Lastly, physiological human factors, such as age, body weight, gender, health condition, or ethnicity, will influence pharmacokinetic behaviors. ${ }^{109}$ The inclusion and exclusion criteria may include characteristics of subjects to indicate that such a human PK study is specific for a certain clinical phase of drug development. ${ }^{110}$

Therefore, without fixing experimental conditions, there is no baseline for the experimental results of different human PK studies to be compared. ${ }^{111}$ It is scientifically correct for the district court to find that "measurements from human PK studies vary widely

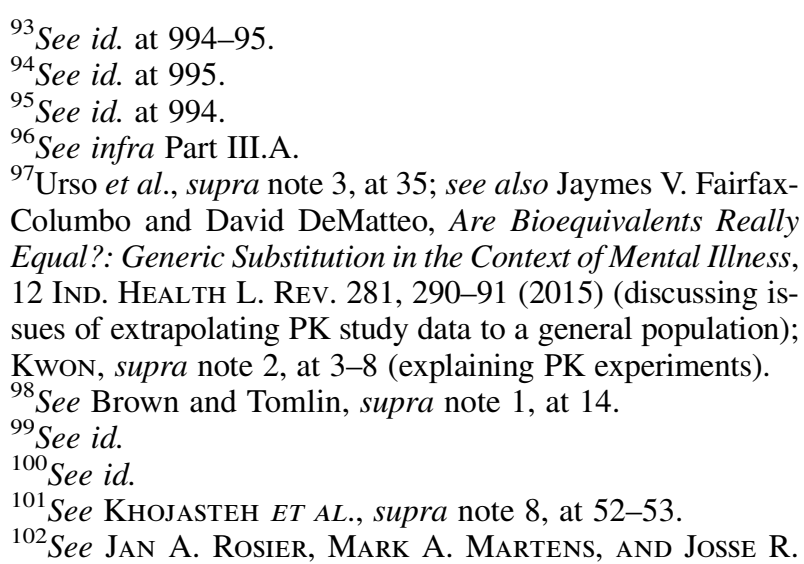
Thomas, Global New Drug Development: An IntroDUCTION 241 (John Wiley \& Sons, Ltd 2014).

${ }^{103}$ See id.

${ }^{104}$ See id.

${ }^{105}$ See id.

${ }^{106}$ See Nina E. Kontny et al., Minimization of the Preanalytical Error in Plasma Samples for Pharmacokinetic Analyses and Therapeutic Drug Monitoring-Using Doxorubicin as an Example, 33 Therapeutic Drug Monitoring 766, 76668 (2011), available at https://pdfs.semanticscholar.org/ 47b6/3a218991d4450f643d242557ef39959f7645.pdf (last visited Dec. 31, 2018); see also Charlotte I.S. Barker et al., Pharmacokinetic Studies in Children: Recommendations for Practice and Research, 103 ARCHIVES OF DISEASE IN Childhood 695, 696-97 (2018), available at https:// adc.bmj.com/content/archdischild/103/7/695.full.pdf (last visited Dec. 30, 2018).

${ }^{107}$ See Kontny et al., supra note 106 , at 766.

${ }^{108}$ See Jeffrey G. Supko et al., Clinical Pharmacology of Anticancer Drugs, in Blood: Principles and Practice of Hematology (Vol. 1) 2095, 2097 (Robert I. Handin, Samuel E. Lux, and Thomas P. Stossel eds., Lippincott Williams \& Wilkins 2003).

${ }^{109}$ See Brown and Tomlin, supra note 1, at 41-44.

${ }^{110}$ See Rosier, Martens, AND Thomas, supra note 102, at 226-251 (describing experimental designs for each clinic phase of drug development).

${ }^{111}$ See D. Shin et al., A Randomized Phase I Comparative Pharmacokinetic Study Comparing SB5 with Reference Adalimumab in Healthy Volunteers, 42 J. ClinICAL PHARMACY \& THERAPEUTICS 672, 673-77 (2017) (recruiting three subject groups of similar characteristics to study pharmacokinetics for three drugs, one of which is biosimilar to the other two). 
in terms of the [plasma] concentration profiles they generate." 112

\section{B. Patent drafting issue}

The finding of indefiniteness in Forest Labs., Inc. resulted from the lack of disclosure in the specification of the '209 Patent. ${ }^{113}$ The district court found that the specification failed to disclose "any human $P K$ study." ${ }^{114}$ However, the description associated with Example 19 in the specification was actually related to a human PK study. ${ }^{115}$

A typical human PK study has been described in Jaroslav Chládek et al. ${ }^{116}$ The Chládek paper describes how subjects were selected for the tablet study and oral solution study, respectively. ${ }^{117}$ The description starts with the basic characteristics of subjects for both studies. ${ }^{118}$ All selected subjects were male non-smokers not taking other medication. ${ }^{119}$ The exclusion criteria included "renal insufficiency, liver, gastrointestinal, cardiovascular, neurological, psychiatric and haematological diseases." 120

The Chládek paper also shows how the subjects took drugs. ${ }^{121}$ The subjects were dosed for 22 days and on the last day, stayed at the test site for 24 hours for blood sampling. ${ }^{122}$ The blood samples were collected from "the antecubital veins immediately before drug administration and at 1, 2, 3, 4, 5, $6,8,10,12,14,16$ and 24 [hours] thereafter." 123 Each sample was $10 \mathrm{ml}^{124}$

Finally, the Chládek paper explains the measurement for plasma concentrations. ${ }^{125}$ Each blood sample was collected through monovettes containing $\mathrm{NH}_{4}$-heparinate as an anticoagulant and centrifuged in a cooling centrifuge to extract the plasma. ${ }^{126}$ Plasma concentrations were determined by a fully validated gas chromatography assay with electron capture detection. ${ }^{127}$ The plasma sample preparation was also described in detail. ${ }^{128}$

The description concerning Example 19 in the '209 Patent is similar to the human PK study described in the Chládek paper. ${ }^{129}$ Example 19 shows a study for determining safety and tolerability of increased dosing for the claimed drug formulation. ${ }^{130}$ The description relevant to the study includes dosages, oral route, characteristics of the subjects, and blood sampling times. ${ }^{131}$ However, there is no information on blood sampling techniques and the inclusion or exclusion criteria of subjects. ${ }^{132}$ In addition, to provide the experimental conditions, the specification uses a table format rather than descriptive sentences as the Chládek paper does. ${ }^{133}$ Therefore, compared with the description of the human PK study design in the Chládek paper, the '209 Patent provides incomplete information. ${ }^{134}$
In addition to Example 19, Example 16 in the specification discloses a predicted plasma concentration of the claimed drug formulation, as shown in Fig. 2D. ${ }^{135}$ The predicted plasma concentration was made by GastroPlus Software package V.4.0.2, the pharmacokinetic software provided by Simulations Plus. ${ }^{136}$ The software simulation was based on the data associated with the in vitro dissolution profile of the claimed drug formulation. ${ }^{137}$ However, the district court criticized that "[s]imulated data is not actual measurements in humans[.]"138

Actually, the modeling procedure of GastroPlus starts with selection of an absorption model. ${ }^{139}$

${ }^{112}$ See Forest I, 2016 WL 54910, at *9.

${ }^{113}$ See infra Part III.B.

${ }^{114}$ Forest I, 2016 WL 54910, at *8 (emphasis original).

${ }^{115}$ See infra Part III.B.

${ }^{116}$ See Jaroslav Chládek et al., Steady-State Bioequivalence Studies of Two Memantine Tablet and Oral Solution Formulations in Healthy Volunteers, 6 J. APPLIED BIOMEDICINE 39, 40-41 (2008).

${ }^{117}$ See id. at 40.

${ }^{118}$ See id.

${ }^{119}$ See id.

${ }^{120} \mathrm{Id}$.

${ }^{121}$ See id.

${ }^{122}$ See id.

${ }^{123} \mathrm{Id}$.

${ }^{124}$ See id.

${ }^{125}$ See id. at $40-41$.

${ }^{126}$ See id. at $40-41$.

${ }^{127}$ See id. at 41.

${ }^{128}$ See id.

${ }^{129}$ See infra Part III.B.

${ }^{130}$ See U.S. Patent No. 8,168,209 col. 30 11. 53-66, col. 3111. $1-25$.

${ }^{131}$ See id.

${ }^{132}$ See id.

${ }^{133}$ See id.

${ }^{134}$ See id. The '209 Patent may be intended not to disclose the experimental results of Example 19, because the specification states that "[t]he study results are expected establish a maximum administerable dose greater than $20 \mathrm{mg}$ when given once per day[.]" U.S. Patent No. 8,168,209 col. 30 11. 60-65 (emphasis added).

${ }^{135}$ See U.S. Patent No. 8,168,209 col. 29 11. 50-66.

${ }^{136}$ See U.S. Patent No. 8,168,209 col. 6 1l. 59-60, col. 2911. 50-60.

${ }^{137}$ See U.S. Patent No. 8,168,209 col. 29 11. 55-56.

${ }^{138}$ Forest I, 2016 WL 54910, at *8.

${ }^{139}$ See Min-Ho Park et al., Prediction of Pharmacokinetics and Drug-Drug Interaction Potential Using Physiologically Based Pharmacokinetic (PBPK) Modeling Approach-A Case Study of Caffeine and Ciprofloxacin, 21 Korean J. Physiology \& Pharmacology 107, 108 (2017), available at https://pdfs.semanticscholar.org/e53b/4c26dcc8f293493 176ee10b4d8280e374522.pdf (last visited Jan. 7, 2018). 
Then, some data, such as solubility, permeability, $\log$, particle size, acid dissociation constant (pKa), must be input into the software module. ${ }^{140}$ Ultimately, some mathematical equations will be used to calculate PK parameters. ${ }^{141}$ As one scholarly paper has cautioned, "it should be emphasized that these simulations are quite dependent on the quality of the input parameters and mechanistic understanding of the processes driving PK." 142 Thus, the district court correctly held that "simulations are models of what could hypothetically be measured." 143

It is not clear why the specification of the '209 Patent does not list the description of human PK study design that follows the simulation results of Example 16. As the district court commented, "[o]ther drafting solutions may also have been available." ${ }^{144}$ Had the specification reported a human PK study protocol for the claimed drug formulation, the '209 Patent would have been saved from invalidation for indefiniteness.

\section{Disclaimer as a savior}

The reason for lack of information on a specific human PK study in the '209 Patent may be implied from the prosecution history. ${ }^{145}$ The '209 Patent was a division application of U.S. Application No. 11/285,905, now U.S. Patent No. 7,619,007 (hereinafter '007 Patent). ${ }^{146}$ When the '007 Patent was filed on November 22, 2005, the original claims included Group I claims for a composition comprising a modified release coating or matrix and an NMDA receptor antagonist, ${ }^{147}$ Group II claims for a composition comprising memantine and a sustained release coating or matrix, ${ }^{148}$ Group III claims for a method of treating, preventing or reducing a neurologic or neuropsychiatric condition, ${ }^{149}$ and Group IV claims for a method of preparing a pharmaceutical composition for the treatment of a condition associated with a deregulation in NMDA receptor activity. ${ }^{150}$

Group I composition claims were featured with an in vitro dissolution profile, ${ }^{151}$ while Group II composition claims were featured with a release rate of memantine. ${ }^{152}$ All composition claims did not recite plasma concentrations. ${ }^{153}$ Thus, the original claim drafting may imply that the applicant for the '007 Patent had never thought about a pharmacological aspect of claiming the inventions.

It is now clear that after Forest Labs., Inc., a claim with plasma concentration-time profiles would be found indefinite if the specification fails to identify a particular human PK study. ${ }^{154}$ But the question is whether a patent application like the '209 Patent could be saved from being held indefinite. The district court's decision may provide some ideas. ${ }^{155}$

The district court suggested that during prosecution of the '209 Patent, "the patentees could have specified a particular profile or collection of profiles or parameters with respect to the "human PK study' limitation." ${ }^{156}$ Although finding that the Went declaration submitted during prosecution disclosed a human PK study, the district court held that "there is no proper basis to limit the 'study' in the patents' claims ... to just the single study included with [the] declaration[.]" 157 The district court emphasized that "there is no disclaimer or disavowal." 158

The district court's reasoning indicates that the applicant for the '209 Patent could have disclaimed or disavowed the claim scope of "human PK study" to make the representative claim definite.

It is a general rule that " $[\mathrm{t}]$ he words of a claim are generally given their ordinary and customary meaning as understood by a person of ordinary skill in the art when read in the context of the specification and prosecution history." 159 One exception is that "the patentee disavows the full scope of a claim term either in the specification or during prosecution." 160 Therefore, disclaimer or disavowal is actually a

\footnotetext{
${ }^{140}$ See id.

${ }^{141}$ See id.

${ }^{142}$ See id.

${ }^{143}$ Forest I, 2016 WL 54910, at $* 8$ (emphasis original).

${ }^{144} I d$. at $* 9$.

${ }^{145}$ See infra Part III.C.

${ }^{146}$ See U.S. Patent No. 8,168,209 col. 1 11. 6-10.

${ }^{147}$ See U.S. Patent Publication No. 2006/0142398 claims 1-20.

${ }^{148}$ See U.S. Patent Publication No. 2006/0142398 claims 21-28.

${ }^{149}$ See U.S. Patent Publication No. 2006/0142398 claims 29-47.

${ }^{150}$ See U.S. Patent Publication No. 2006/0142398 claims 48-58.

${ }^{151}$ See U.S. Patent Publication No. 2006/0142398 claim 1.

${ }^{152}$ See U.S. Patent Publication No. 2006/0142398 claim 21.

${ }^{153}$ See U.S. Patent Publication No. 2006/0142398 claims 1-28.

${ }^{154}$ See supra Part II.

${ }^{155}$ See infra Part III.C.

${ }^{156}$ Forest I, 2016 WL 54910, at *9.

${ }^{157} I d$.

${ }^{158}$ Id. (citing Thorner v. Sony Computer Entm't Am. LLC, 669 F.3d 1362, 1366-67 (Fed. Cir. 2012)).

${ }^{159}$ Thorner v. Sony Computer Entm't Am. LLC, 669 F.3d 1362, 1365 (Fed. Cir. 2012).

${ }^{160}$ Id.
} 
way to limit the scope of a claim. ${ }^{161}$ But now disclaimer or disavowal may be a way to save a claim from being held indefiniteness.

The question then is what an applicant should have done during prosecution to limit the claim scope for purposes of overcoming indefiniteness. The Federal Circuit case law has required a finding of "a clear and unmistakable disavowal during prosecution [to overcome] the heavy presumption that claim terms carry their full ordinary and customary meaning." 162 That is, a patentee must "unequivocally and unambiguously disavow[] a certain meaning to obtain a patent[.]"163 Besides, "[a] statement made during prosecution of related patents may be properly considered in construing a term common to those patents, regardless of whether the statement pre- or post-dates the issuance of the particular patent at issue." 164

In Biogen Idec, Inc. v. GlaxoSmithKline LLC, the issue related to disclaimer was how the patent examiner and applicant understood the disputed term, "anti-CD20 antibody," in U.S. Patent No. 7,682,612 (hereinafter, '612 Patent). ${ }^{165}$ The '612 Patent relates to treatment for patients with Chronic Lymphocytic Leukemia (CLL) by using anti-CD20 antibodies like Rituxan (rituximab). ${ }^{166} \mathrm{CLL}$ is a cancer in which the bone marrow makes too many B lymphocytes ("B cell"), a type of white blood cell. ${ }^{167}$

The patentee argued that the full ordinary and customary meaning of "anti-CD20 antibody" was "an antibody that binds to a cell surface CD20 antigen." 168 But the Federal Circuit agreed with the district court's narrow construction limiting the disputed term to "rituximab and antibodies that bind to the same epitope of the CD20 antigen with similar affinity and specificity as rituximab." 169

The Federal Circuit relied on the prosecution history showing the enablement issue raised by the examiner who considered the specification as only enabling the inventions for Rituxan, rituximab, and 2B8-MX-DTPA, but not for any and all antiCD20 antibodies as the disputed claims require. ${ }^{170}$ Rather than challenging the examiner's characterization of the claimed invention, the applicant argued that the specification enabled the inventions for "anti-CD20 antibodies with similar affinity and specificity as Rituxan ${ }^{\circledR} . " 171$ In fact, the applicant conceded that antibodies directed to CD20 might have different affinities and functional characteristics and limited the disputed claims to antibodies similar to Rituxan. ${ }^{172}$ Therefore, the Federal Circuit concluded that the district court correctly applied prosecution history disclaimer to the interpretation of "anti-CD20 antibody."

Likewise, to narrow the claim scope of "human PK study" to a specific human PK study, the appli- cant for the '209 Patent would have made a statement during prosecution to specify the experimental design of such human PK study in details. Unfortunately, the Went declaration failed to do so. ${ }^{174}$

The Went declaration described a human PK study, but it provided limited information on the study design. ${ }^{175}$ The experimental description included the number of subjects that were divided into four groups, qualities of a drug taken by the subjects of each group, and the times of blood sample collection. ${ }^{176}$ However, the description mentioned nothing about the method of administration, physiological characteristics of the subjects, and blood sampling techniques. ${ }^{177}$ Thus, a particular human PK study could not have been identified.

In addition, the remarks made in association with the Went declaration described the declaration as evidence that demonstrates unexpectedly superior results caused by the claimed formulations to overcome the obviousness rejection. ${ }^{178}$ The remarks did

${ }^{161}$ See Biogen Idec, Inc. v. GlaxoSmithKline LLC, 713 F.3d 1090, 1095 (Fed. Cir. 2013) ("[W]hen the patentee unequivocally and unambiguously disavows a certain meaning to obtain a patent, the doctrine of prosecution history disclaimer narrows the meaning of the claim consistent with the scope of the claim surrendered.").

${ }^{162} I d$. (international quotation marks omitted and emphasis added).

${ }^{163} I d$. (emphasis added).

${ }^{164}$ Teva Pharm. USA, Inc. v. Sandoz, Inc., 789 F.3d 1335, 1343 (Fed. Cir. 2015).

${ }^{165}$ See id.

${ }^{166}$ See id. at 1092.

${ }^{167}$ See Chronic Lymphocytic Leukemia Treatment $\left(\mathrm{PDQ}^{\circledR}\right)$ Patient Version, https://www.cancer.gov/types/leukemia/ patient/cll-treatment-pdq (last visited Jan. 13, 2019); see also Biogen Idec, Inc., 713 F.3d at 1092.

${ }^{168}$ Biogen Idec, Inc., 713 F.3d at 1092.

${ }^{169} I d$.

${ }^{170}$ See id. at $1095-96$.

${ }^{171}$ Id. at 1096.

${ }^{172}$ See id. at 1096.

${ }^{173}$ See id. at 1096-97.

${ }^{174}$ See infra Part III.C.

${ }^{175}$ See Declaration under 37 C.F.R. $§ 1.132$ (filed Dec. 21, 2011 ) in the File Wrapper of U.S. Patent No. 8,168,209, at 3, archived at https://drive.google.com/file/d/1L8WnoFlcb2v vCZP2VFENf_x9US4JhnzG/view?usp=sharing (last visited Jan. 14, 2019).

${ }^{176}$ See id.

${ }^{177}$ See id.

${ }^{178}$ See Remarks (filed Dec. 21, 2011) in the File Wrapper of U.S. Patent No. 8,168,209, at 9, archived at https://drive .google.com/file/d/103m7MLIbs234IhZM7_pQr8kuhkux Dwo/view? usp=sharing (last visited Jan. 15, 2019). FNTX> 
not clarify the experimental conditions of the human PK study mentioned in the declaration. ${ }^{179}$

Therefore, for those pending applications like the '209 Patent that require reading a "human PK study" limitation into the claims, it is recommended that applicants file a declaration made by the inventors to specify the experimental conditions of such a human PK study in detail. With that, the claims may be held definite in later litigation.

\section{CONCLUSION}

Forest Labs., Inc. teaches that when "human PK study" is used to describe plasma concentration- time profiles in a claim, a drafter should identify a specific human PK study protocol in the specification to avoid finding such claim indefinite. The specification should describe a route of administration, dosage regimen, blood sampling technique, and characteristics of subjects, as required in the academic context. For those pending applications like the '209 Patent, the applicants may file a declaration made by the inventors to specify the design of such a human PK study, which may constitute a disclaimer or disavowal to limit the scope of the "human PK study" limitation to make the claims definite under 35 U.S.C. $\S 112$.

\footnotetext{
${ }^{179}$ See id. at $9-17$.
} 